\title{
Vitamin E as an Antioxidant in Female Reproductive Health
}

\author{
Siti Syairah Mohd Mutalip ${ }^{1, * \mathbb{B}}$, Sharaniza Ab-Rahim ${ }^{2}$ and Mohd Hamim Rajikin ${ }^{2}$ \\ 1 Faculty of Pharmacy, Universiti Teknologi MARA (UiTM) Puncak Alam Campus, Selangor 42300, Malaysia \\ 2 Faculty of Medicine, Universiti Teknologi MARA (UiTM) Sg. Buloh Campus, Selangor 42300, Malaysia; \\ sharaniza_abrahim@salam.uitm.edu.my (S.A.-R.); hamim400@salam.uitm.edu.my (M.H.R.) \\ * Correspondence: syairah@puncakalam.uitm.edu.my; Tel.: +60-03-3258-4840
}

Received: 11 December 2017; Accepted: 25 January 2018; Published: 26 January 2018

\begin{abstract}
Vitamin E was first discovered in 1922 as a substance necessary for reproduction. Following this discovery, vitamin E was extensively studied, and it has become widely known as a powerful lipid-soluble antioxidant. There has been increasing interest in the role of vitamin $\mathrm{E}$ as an antioxidant, as it has been discovered to lower body cholesterol levels and act as an anticancer agent. Numerous studies have reported that vitamin E exhibits anti-proliferative, anti-survival, pro-apoptotic, and anti-angiogenic effects in cancer, as well as anti-inflammatory activities. There are various reports on the benefits of vitamin $\mathrm{E}$ on health in general. However, despite it being initially discovered as a vitamin necessary for reproduction, to date, studies relating to its effects in this area are lacking. Hence, this paper was written with the intention of providing a review of the known roles of vitamin $\mathrm{E}$ as an antioxidant in female reproductive health.
\end{abstract}

Keywords: vitamin E; reproduction; antioxidant; tocopherol; tocotrienol

\section{Vitamin $\mathrm{E}$}

Vitamin E was first discovered by Evans and Bishop in 1922, and it was initially denoted as an "anti-sterility factor X" that was necessary for reproduction [1]. Since then, vitamin $\mathrm{E}$ has been well characterized as a powerful lipid-soluble antioxidant through extensive research. The antioxidant activities of vitamin $\mathrm{E}$ were reported following findings on its ability to scavenge reactive oxygen species (ROS) in cellular membranes [2-4].

\subsection{Sources of Vitamin E}

Vitamin E, which consists of a mixture of tocopherols (TOCs) and tocotrienols (TCTs), is available in a number of foods and plants, ranging from edible oils to nuts. Some vitamin E-containing foods include wheat, rice bran, barley, oat, coconut, palm and annatto $[5,6]$. Other sources include rye, amaranth, walnut, hazelnut, poppy, safflower, maize and the seeds of grape and pumpkins. Vitamin E derivatives have also been detected in human milk [7] and palm dates (Phoenix canariensis) [8]. Among the many sources of vitamin E, rice bran, palm oil and annatto oil have been described as the richest sources of TCTs [9].

\subsection{Structure of Vitamin $E$}

Vitamin E consists of a mixture of tocopherols (TOCs) and tocotrienols (TCTs) that are synthesized by plants from homogenestic acid [10]. These substances are present in eight different homologues; namely, $\alpha$-tocopherol, $\beta$-tocopherol, $\gamma$-tocopherol, $\delta$-tocopherol, $\alpha$-tocotrienol, $\beta$-tocotrienol, $\gamma$-tocotrienol and $\delta$-tocotrienol [11]. The four TOC homologues $(\alpha-, \beta-, \gamma-, \delta$-TOC) have a fully saturated 16-carbon isoprenoid sidechain, while TCT homologues have a similar isoprenoid 
chain, containing three double bonds (an unsaturated side chain). The TOC homologues are named with respect to the position and number of the methyl groups on the phenol ring. The $\alpha-, \beta-, \gamma-$ and $\delta$-homologues contain three, two, two and one methyl groups, respectively (Figure 1 ). These structural differences and the isomerism determine the biological activity, with $\alpha$-homologues being the most biologically active [12]. However, it has been reported that light, temperature, and oxygen availability could promote rancidity in vegetable oils [13]. According to a study [13], soybean oil that was stored in the dark for 56 days had increased peroxide value. In addition, its exposure to light in a $12 \mathrm{~h}$ light/darkness cycle over for 56 days resulted in an increase in peroxide values of around $1473 \%$.

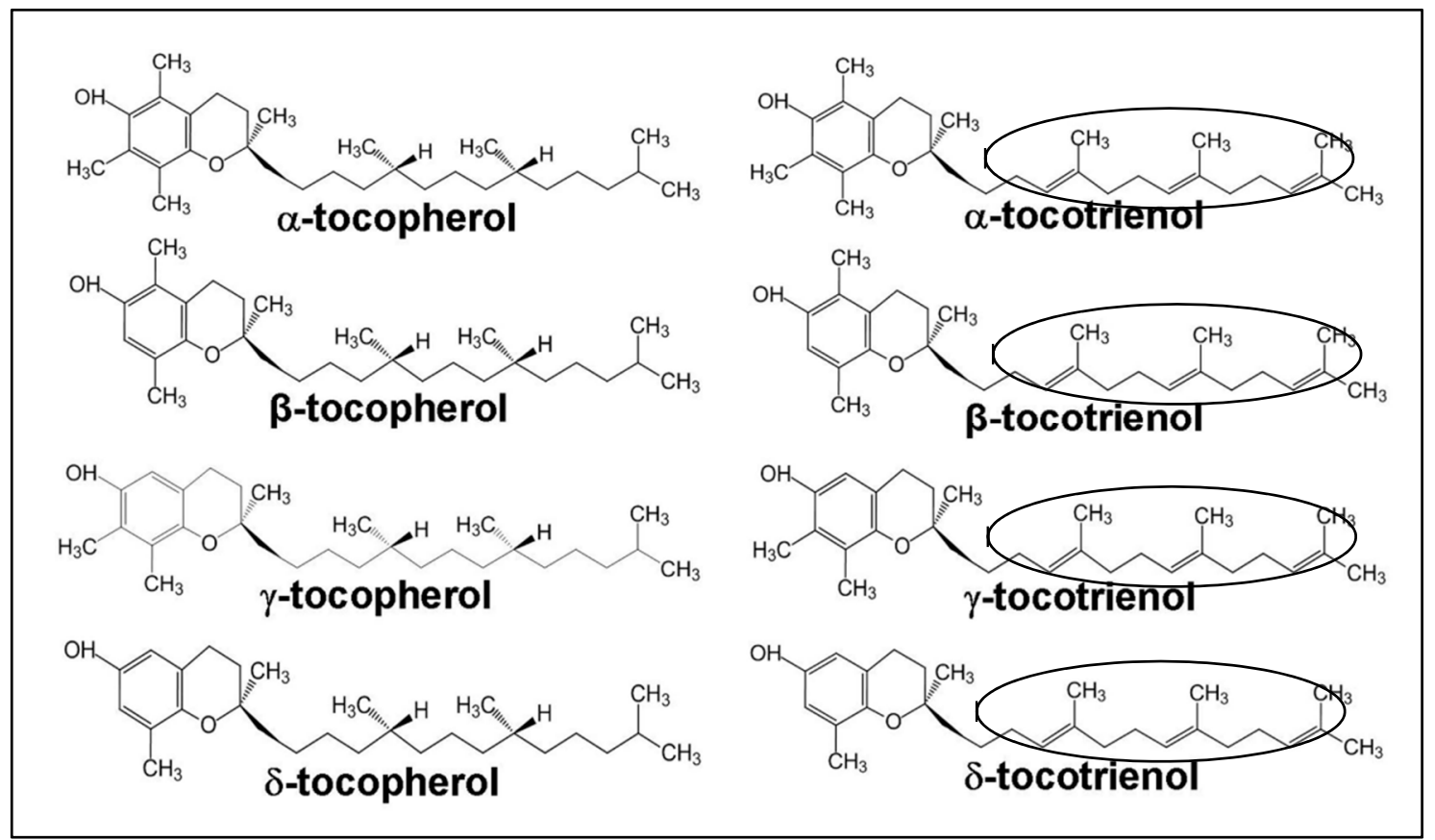

Figure 1. Structure differences between tocopherols (TOCs) and tocotrienols (TCTs). TOCs have saturated side chains, while TCTs have unsaturated side chains. The latter are shown by the presence of three double bonds in TCTs (circled) [14].

\section{Reproductive Disorders: The Risk Factors}

A number of risk factors contributing to reproductive- and pregnancy-related disorders have been previously reported [15-17]. These factors are generally categorized into two major groups: environmental and lifestyle factors. Examples of major environmental pollutants include hazardous man-made chemicals, industrial discharge, agricultural run-off, human and animal waste, municipal and domestic effluents, and spillage of vessels and oil spills [17]. Exposure to these pollutants during the time of periconceptional period (periconceptional period refers to the time of preconception, conception, implantation, placentation and embryogenesis (or organogenesis) stages of pregnancy) were reported to have adverse effects on the development of conceptus and the neonatal health [15]. These include the risks of embryonic mortality and fetal loss, intrauterine growth restriction (IUGR), birth defects, childhood diseases, premature sexual maturation and a few types of adult cancers [15]. Additionally, Rider et al. [16] also reported that exposure of conceptus to multiple environmental pollutants in utero during pregnancy could affect embryonic implantation and the developmental course in a cumulative dose-additive manner.

Exposure to multicomponent mixtures of endocrine-disturbing chemicals may act as hormone mimics or antagonists, leading to the disruption of estrogen, androgen and other hormonal pathways [18]. Furthermore, exposure to multiple environmental pollutants may also result in reactive oxygen species (ROS)-induced oxidative stress (OS) [19-21]. The presence of high levels of OS may 
be a risk factor for a number of pregnancy-related disorders, such as embryonic mortality, early spontaneous abortion, IUGR, fetal death, premature delivery and low birth weight [22,23].

Lifestyle factors represent another category of major risk factors for reproductive and pregnancyrelated disorders. Unhealthy lifestyle behaviors, including cigarette smoking, alcohol consumption, and/or drug abuse, have negative impacts, particularly on female fertility [24,25]. The underlying mechanism of the developmental defects following these unhealthy lifestyle behaviors is mainly a result of an increase in ROS production and associated OS-induced cellular damage [26]. There are also extensive epidemiological studies which have reported on a number of factors such as exposure to tobacco and alcohol, diet, stress, and gestational diabetes as the factors influencing fetal development including miscarriages [27-29].

Much evidence-based epidemiological, clinical, and experimental data on the adverse effects of cigarette smoking on female reproductive health has been reported [30]. The effects of smoking on steroidogenesis, folliculogenesis embryo transport, endometrial receptivity, endometrial angiogenesis, uterine blood flow, and uterine myometrium, all of which are related to delayed or failed implantation and pregnancy loss, have been reported. This is in line with an animal study on the effects of alcohol on reproductive health and pregnancy that indicated that prenatal exposure to ethanol in rats induced hypothalamic OS and neuroendocrine alterations in offspring [31]. Furthermore, excess ethanol administration to pregnant mice [32] and rats [33] caused disturbances in embryogenesis and increased the rate of malformations and fetal death by inducing high levels of OS. Medication use or drug abuse during pregnancy has also been associated with OS [34,35]. Phenytoin [36], thalidomide [37], valproic acid [38], almokalant, dofetilide, cisapride and astemizole [39] are the examples of identified medical drugs known to induce OS and affect the embryonic development leading to birth defects.

To explain further, maternal smoking during pregnancy has been widely recognized as one of the most common factors of reproductive- and pregnancy-related disorders. Cigarette smoke contains a complex mixture of numerous toxic constituents including nicotine, polycyclic aromatic hydrocarbons, and cadmium $[30,40]$. The different constituents of the mixture cause an increased level of OS and adversely affect the cell proliferation and differentiation during embryonic development in pregnant female smokers [41]. This is supported by studies on the effects of maternal smoking during pregnancy, showing that cigarette smoking is associated with spontaneous abortion [42], placenta previa and placental abruption [43-45], low birth weight and preterm birth [46-48], stillbirth [49,50] and sudden infant death syndrome (SIDS) [51].

One of the most important cigarette smoke constituents, nicotine, has been reported to reduce fertility during adulthood in women [52]. In addition, cotinine (a metabolite of nicotine), cadmium, and benzo[a]pyrene have also been detected in the follicular fluid of smoking women [53-55], suggesting that the chemicals present in cigarette smoke can accumulate in the ovary. The results of these studies suggested that smoking women might develop impaired fertility, resulting from the combination of deteriorated oocyte function and viability $[53,56,57]$.

In addition, laboratories studies have indicated that maternal exposure to cigarette smoke or cigarette smoke condensate (CSC) for 4 weeks results in the increased oocyte fragmentation or delayed fertilization, thus reducing the embryonic development to blastocysts in vitro [58]. Additionally, fragmented oocytes also showed increased production of ROS. Another study on the effects of nicotine on early embryogenesis in murine embryos reported that embryos treated with 3-6 $\mu \mathrm{M}$ of nicotine were smaller than control embryos [59]. Meanwhile, embryos treated with $6 \mu \mathrm{M}$ of nicotine showed severe defects in the posterior trunk, resembling caudal dysplasia [59]. In addition, excessive apoptosis was also observed in the deformed structures and this was associated with the increased levels of ROS [59]. Nicotine exposure during fetal and neonatal development was also reported to cause reduction in fertility, dysregulation in ovarian steroidogenesis, and alterations in follicle dynamics in female offspring [60]. This has been further supported by another study which reported that treatment with $5 \mathrm{mg} / \mathrm{mL}$ nicotine beginning from day 1 of pregnancy throughout gestation decreased the pregnancy rates by 33.3\% in Sprague-Dawley rats [61]. Another study by Rajikin et al. [62] reported 
that the ultrastructure of oocytes from nicotine-exposed mice showed a non-spherical shape with rough surface and torn zona pellucida. In addition, treatment with $5 \mathrm{mg} / \mathrm{kg}$ nicotine for 30 days increased the apoptosis rate in oocytes [63]. Meanwhile, productions of hatched blastocysts were decreased following injection with $1 \mathrm{mg} / \mathrm{kg}$ and $3 \mathrm{mg} / \mathrm{kg}$ of nicotine, and embryonic development ceased at the morula stage following exposure to $5 \mathrm{mg} / \mathrm{kg}$ of nicotine [64]. This was in line with the work of Phoebe et al. [65], which showed that after 12 weeks of cigarette smoking (directly to the lungs) in mice, the retrieved oocytes had a significantly thicker zona pellucida, and also shorter and wider meiotic spindles.

\section{Oxidative Stress (OS) as One of the Risk Factors in Reproductive Disorders}

Oxidative stress (OS) is widely recognized as the key element in the pathogenesis of most of the diseases [66], and occurs when there is an imbalance in the presence of antioxidants and pro-oxidants $[20,22,67]$. Excess pro-oxidants induce OS by either generating reactive oxygen species (ROS) or by inhibiting antioxidant systems [68]. ROS are highly reactive and unstable. They acquire electrons from nucleic acids, lipids, proteins, carbohydrates, or any other nearby molecule causing a string of chain reactions to become stable. These chain reactions result in cellular damage and diseases [69].

In the female reproductive system, ROS can impair cellular functions and subsequently interrupt intracellular homeostasis and furthermore lead to cell damages. The presence of excess ROS can influence early embryonic development through modification of the key transcription factors that modify gene expressions [70]. High concentrations of ROS in the female reproductive tract could also negatively affect the fertilization of oocytes and cause inhibition of embryonic implantation [71,72]. Additionally, earlier studies reported that OS is involved in defective and retarded embryonic development due to OS-induced cell-membrane damage, DNA damage, and apoptosis [73,74]. Apoptosis results in the formation of fragmented embryos which have limited chances of implantation and growth [75].

Previous studies on the effect of OS during the periconceptional period have shown that the placenta could be the key source of OS because of the high metabolic rate and increase in the mitochondrial activities [76,77]. During the first trimester, placental tissues contain low concentrations and activities of principle antioxidant enzymes including catalase, glutathione peroxidase, and superoxide dismutase. This condition may expose the embryonic trophoblast cells to oxygen-mediated damage [78]. An earlier study reported that due to the increase in the oxygen tension during the onset of maternal arterial flow during the beginning of second trimester, a burst of OS was observed in the placenta [79]. The study suggested that this oxidative injury could adversely impair placental remodeling and functions that would subsequently affect the course of gestation [79]. This was further supported by Jauniaux et al. [80], who found that high production of ROS and reduced antioxidant defense capability might cause the developing fetus to be exposed to increased OS.

According to other reports, macromolecule damage mediated by OS has been suggested as a mechanism of thalidomide-induced embryopathy and other embryopathies [81,82]. This suggestion was supported by an experimental finding on untreated pregnant mutant mice with a hereditary glucose-6-phosphate dehydrogenase (G6PD) deficiency that resulted in decreased litter size at birth and increased pre- and post-natal (pre-weaning) death. G6PD is a cytoprotective enzyme for OS. This result indicated that a physiological level of endogenous OS due to a dysfunctional G6PD enzyme during development can cause embryopathy that might lead to both infertility and death [83].

Oxidative stress in the female reproductive system is generally reported in most reproductive- and pregnancy-related disorders. For instance, OS has been associated with endometriosis. Although there is no established information on the involvement of OS in endometriosis, a number of studies have reported on the increased level of OS markers in patients with endometriosis [84-90]. Additionally, OS also has been reported to be involved in cases of spontaneous abortion and idiopathic recurrent 
pregnancy loss [66,78,80,91], unexplained infertility [92-94], preeclampsia [95-97], intrauterine growth restriction (IUGR) [98,99] and preterm labor [100-103].

\section{Antioxidants and Their Roles in Reproductive Disorders}

Antioxidants regulate the overproduction of ROS. They are present in two types, enzymatic and non-enzymatic forms. Enzymatic antioxidants, including superoxide dismutase (SOD), catalase, glutathione (GSH) peroxidase and glutathione (GSH) reductase are also known as natural antioxidants or endogenous antioxidants $[66,104]$. The non-enzymatic antioxidants, also known as exogenous antioxidants, are obtained from dietary fruits and vegetables. These include taurine, hypotaurine, $\beta$-carotene, selenium, zinc, vitamin C and vitamin E [66].

The roles of antioxidants during the periconceptional period have been previously reported $[105,106]$. Endogenous antioxidants play important roles within the placenta as well as in the protection of trophoblast cells from OS [106]. It has been reported that SOD has a primary role in cellular protection, metabolizing two molecules of superoxide $\left(\mathrm{O}_{2}{ }^{-}\right)$to produce hydrogen peroxide $\left(\mathrm{H}_{2} \mathrm{O}_{2}\right)$ and molecular oxygen $\left(\mathrm{O}_{2}\right)$. Meanwhile, catalase (predominantly located in the peroxisomes) catalyzes the conversion of $\mathrm{H}_{2} \mathrm{O}_{2}$ to $\mathrm{O}_{2}$ and water $\left(\mathrm{H}_{2} \mathrm{O}\right)$. GSH peroxidase and $\mathrm{GSH}$ reductase are involved in oxidizing glutathione peroxides by removing $\mathrm{H}_{2} \mathrm{O}_{2}$ and lipid hydroperoxides [106].

Another antioxidant system that is highly available in the placental cells is the thioredoxin system [105]. This system consists of three antioxidant enzymes; namely, thioredoxin peroxidase, thioredoxin, and thioredoxin reductase. Thioredoxin peroxidase catalyzes the conversion of $\mathrm{H}_{2} \mathrm{O}_{2}$ and alkyl hydroperoxides to $\mathrm{H}_{2} \mathrm{O}$ and corresponding alcohols. This reaction results in the oxidation of thioredoxin peroxidases to an inactive state requiring reduction by thioredoxin [105]. Thioredoxins have been reported to be involved in a number of cellular functions, including cell growth [107], reduction of thioredoxin peroxidase [105], inhibition of apoptosis through the binding of apoptosis signal-regulating kinase-1 (ASK-1) [108], and the supply of electrons for the synthesis of deoxyribonucleotides by ribonucleotide reductase [109].

Exogenous antioxidants, in line with their endogenous counterparts, also play a prime role in cellular defense against OS. The effects of maternal taurine deficiency, including growth retardation of the offspring, impaired perinatal development of the central nervous and pancreatic endocrine systems, impaired glucose tolerance, and vascular dysfunction, were reported by Aerts and Van [110]. Another exogenous antioxidant, zinc $(\mathrm{Zn})$ is used in assisting the fetal brain development and also as an aid to the mothers in labor [111]. According to one study, an early and progressive decline in serum Zn occurs during pregnancy, and therefore the capacity for metabolic adaptation of pregnant mothers may be limited if the maternal $\mathrm{Zn}$ status is poor [112]. This is supported by a meta-analysis study on zinc-supplementation in women, which resulted in $14 \%$ of reduction in premature delivery [113].

Vitamin $C$ acts as a reducing agent to protect cells against the adverse effects of OS [114]. Zhang et al. [115] reported that pregnant women who consumed vitamin $C$ at levels lower than the recommended daily allowance $(85 \mathrm{mg}$ ) had a 2-fold higher risk of developing preeclampsia, suggesting the importance of vitamin $C$ supplementation in pregnant women. One randomized controlled clinical trial on patients with luteal phase defects reported that pregnancy rates were higher in the group supplemented with vitamin C (750 mg/day) than in the control group (no treatment) [116]. Another double-blinded, placebo-controlled pilot study on the effect of supplementation containing vitamin E, iron, zinc, selenium and L-arginine resulted in an increase in ovulation and pregnancy rates [117].

Maternal (preeclampsia, abortion, and hypertension) and neonatal outcomes following antioxidant supplementation for 8 to 12 weeks in pregnancy for women with low antioxidant status were reported by Rumiris et al. [118]. This study was a randomized, double-blind, placebo-controlled trial of daily antioxidant supplementation. The supplementation included vitamins A (1000 international unit (IU)), B6 (2.2 mg), B12 (2.2 $\mu \mathrm{g}), \mathrm{C}(200 \mathrm{mg})$, and E (400 IU), folic acid (400 $\mu \mathrm{g})$, $\mathrm{N}$-acetylcysteine (200 mg), Cu (2 mg), Zn (15 mg), Mn (0.5 mg), Fe (30 mg), Ca (800 mg), and selenium 
$(100 \mu \mathrm{g})$. Meanwhile, the control subjects were given ferum $(30 \mathrm{mg})$ and folic acid $(400 \mu \mathrm{g})$. Results from this study indicated that antioxidant supplementation was associated with better maternal and perinatal outcomes in pregnant women with low antioxidant status as compared to control supplementation with iron and folate alone [118].

In addition, vitamin E functioning as a chain-breaking antioxidant was reported to protect cellular membranes against ROS, for example through defending polyunsaturated fatty acids (PUFAs) from auto-oxidation [119]. Antioxidants such as vitamin C and vitamin E have been reported to be efficient, and their uses in reproductive- and pregnancy-related disorders have been the subject of significant clinical trials [120]. For instance, a randomized clinical trial was conducted from January 2007 to February 2008 at the Women's Hospital of Tabriz University of Medical Sciences, Iran. This study was conducted in response to the inadequate available evidence about the role of supplementary vitamin $\mathrm{E}$ in normal pregnancy, and assessed the potential benefit of vitamin E supplementation on health in pregnancy [121]. This trial involved 104 pregnant women who were treated with vitamin $\mathrm{E}$ supplementation, and 168 women (control) who were not treated with the supplementation. Treated women were administered 400 IU vitamin E from week 14 to the end of the pregnancy. The study result indicated a non-significant relationship between supplementation and maternal and perinatal outcomes and birth weight, in which preeclampsia was reported to occur in $1 \%$ of treated women as compared to $1.78 \%$ of women in the control group. From these results, the authors concluded that the administration of supplementary vitamin E starting from the second trimester of pregnancy did not show any risks with respect to pregnancy outcomes and the occurrence of preeclampsia [121].

This is also supported by earlier studies on the possible beneficial effects of supplementary vitamin E during pregnancy, which investigated the changes in vitamin $E$ levels in normal versus problematic pregnancies. Oxidative stability of vitamin E levels was shown to increase in maternal blood during normal pregnancies [122]. Moreover, it has also been shown that vitamin E requirements may increase in some circumstances, such as in smoking during pregnancy [123]. In a comparative study between abnormal and normal pregnancies, the mean levels of vitamin $\mathrm{E}$ were reported to increase from $12.9 \mu \mathrm{g} / \mathrm{mL}$ in early pregnancy to $22.5 \mu \mathrm{g} / \mathrm{mL}$ at term in normal pregnancies. However, vitamin E levels were lower than in normal pregnancies at the corresponding gestational age in abnormal pregnancies [124]. Another study by Tamura et al. [125] on 289 pregnant women in Birmingham, United Kingdom reported that there were no significant associations between vitamin E serum concentrations and pregnancy outcomes. All of these reports suggest that vitamin E is essential for normal and healthy pregnancy, and supplementation of vitamin E does not cause any detrimental effects on pregnancy outcomes.

Another recent study was conducted on the effects of vitamin $\mathrm{E}$ on the treatment outcomes of women with unexplained infertility who were undergoing controlled ovarian stimulation and intrauterine insemination (IUI) [126]. The study was conducted between June 2011 and December 2011 in Zekai Tahir Burak Women's Training and Research Hospital, Reproductive Endocrinology and Infertility Department, Ankara, Turkey. The study groups were divided into Group A $(n=53)$ and Group B $(n=50)$. Group A underwent controlled ovarian stimulation with clomiphene citrate with vitamin E administration at $400 \mathrm{IU} /$ day, while Group B (control) underwent ovulation induction without the vitamin E administration. The results of the study showed that the difference in the endometrial thickness on the day of human chorionic gonadotropin (hCG) administration was significant between the two groups; however, there was no significant association observed between vitamin $\mathrm{E}$ administration and implantation and pregnancy rates. Based on these results, it was concluded that vitamin $\mathrm{E}$ administration could improve endometrial response in women with unexplained infertility through the antioxidant and anticoagulant effects. Vitamin E may also modulate the anti-estrogenic effect of clomiphene citrate. Moreover, the issue of thin endometrium in patients may also be improved by vitamin $\mathrm{E}$ [126].

As discussed above, vitamin $\mathrm{E}$ has been proven to be beneficial in pregnancy and neonatal health. This is in line with previous studies that reported, for instance, plasma $\alpha$-tocopherol concentrations 
that is below than $12 \mathrm{mmol} / \mathrm{L}$ are associated with increased infection, anemia, growth retardation and poor pregnancy outcomes in both mothers and infants (reviewed in [127]). These problems occur mainly because when low dietary amounts of $\alpha$-tocopherol are consumed, the requirements for tissue $\alpha$-tocopherol will exceed the available amounts, resulting in increased damages of the tissues [127].

\section{Vitamin E as an Antioxidant in Female Reproduction: The Reported Studies}

Following the first publication by Evans and Bishop [1], a later report discussed the role of vitamin $\mathrm{E}$ in reproduction after observations in which a vitamin-E deficient diet resulted in uterine discolorations in rats [128]. Decades later, research on the role of vitamin E in reproductive physiology was re-initiated, and it was reported to have beneficial effects against stress-induced oxidative stress (OS) [129-133].

In another study, a population of women suffering habitual abortion was observed to have high levels of lipid peroxidation and decreased levels of plasma vitamin E [129]. Another study conducted in Egypt also reported that vitamin E to be a key missing micronutrient in children with stunted growth [130]. The study showed that $78.2 \%$ of children with stunted growth had vitamin E deficiency, where plasma $\alpha$-TOC concentrations were recorded at $7.7 \mu \mathrm{mol} / \mathrm{L}$ as compared to $14.1 \mu \mathrm{mol} / \mathrm{L}$ in control (normal) children. In addition, a recent report by [131] also indicated that vitamin A, E, and $\mathrm{D}$ deficiencies were very common in very-low-birthweight Tunisian neonates and were associated with preeclampsia.

In more detailed experiments using in vivo laboratory animal models supplemented with palm-tocotrienol rich fractions (TRF), Mokhtar et al. [61] reported that co-administration with $5 \mathrm{mg} / \mathrm{kg}$ body weight (bw) of nicotine and $60 \mathrm{mg} / \mathrm{kg}$ of tocotrienol-rich fraction (TRF) increased the rates of pregnancy to $83.3 \%$ in rats, compared to those treated with nicotine alone, who had pregnancy rates of $33.3 \%$. About $25.7 \%$ of the embryos developed into 2- and 4-cell stage in rats treated with both nicotine and TRF [61]. In addition, there was also a report stating that supplementation with $\gamma$-TCT in nicotine-induced mice reduced the detrimental effects of nicotine on the ultrastructure of the oocytes [62]. Another study conducted using concurrent treatment with corticosterone (CORT) and TCT reported that the numbers of abnormal embryos were reduced following supplementation with $90 \mathrm{mg} / \mathrm{kg}$ and $120 \mathrm{mg} / \mathrm{kg}$ of TCT [134]. Meanwhile, co-administration with $\gamma$-TCT improved the embryonic development in nicotine-induced mice [64]. Moreover, as reported in more recent findings, using co-incubation in media supplemented with $\gamma$-TCT and hydrogen peroxide $\left(\mathrm{H}_{2} \mathrm{O}_{2}\right), \gamma$-TCT improved the development of porcine embryos through modulation of the apoptotic BCL-XL and BAX genes [135]. The beneficial effects of TCTs were also supported by the reports on the concomitant supplementation of TRF with the anti-cancer prodrug, cyclophosphamide (CPA) on ovarian cells, which was reported to provide protection against OS-induced apoptosis in the ovaries [132,133].

An earlier study using supplementation with annatto-TCTs in pregnant Wistar rats reported that no adverse effects, no increase in embryo lethality and no reduction in fetal body weight were observed [136]. These findings were in line with our recent findings, together with our observations on the anti-survival effects of annatto-delta tocotrienol and soy alpha-tocopherol on the preimplantation embryos of nicotine-treated female mice [137-140]. Furthermore, a recent study also reported that annatto-TCTs suppressed cell growth in human prostate cancer cells through inhibition of the Src and Stat3 genes [141].

In addition to the studies in human and laboratory animals, the benefits of vitamin $\mathrm{E}$ have also been studied in domestic animals. An earlier study using the culture of bovine embryos (embryos were derived from the in vitro matured-and-fertilized oocytes) with vitamin E, vitamin $C$, and ethylenediaminetetraacetic acid (EDTA) showed that more zygotes were developed to the expanded blastocyst stage in culture medium containing $100 \mu \mathrm{M}$ of vitamin $\mathrm{E}$ compared to the control medium. The development to the early, expanded, and hatched blastocyst stages were also lower in the culture medium supplemented with both vitamin $\mathrm{E}$ and $\mathrm{C}$, compared to the medium supplemented with vitamin E alone [142]. Moreover, the in vitro-produced embryos were cultured for 5.5 days 
in medium with or without $100 \mu \mathrm{M}$ of vitamin $\mathrm{E}$ and were non-surgically transferred to recipient cows. After 7 days of transfer, the embryos were non-surgically collected, and the results indicated that embryos cultured with vitamin E were approximately $63 \%$ larger in surface area than in the control embryos [142]. Another study by [143] also reported on the effects of antioxidants such as beta-mercaptoethanol (beta-ME) and vitamin $\mathrm{E}$ where both suppressed oxidative damage and improved the developmental ability in the porcine embryos.

The beneficial effects of vitamin E were also studied in buffalos. A study was conducted to find whether the supplementation of vitamin $\mathrm{E}$ in the culture medium could ameliorate the developmental competence of preimplantation buffalo embryos. The study results indicated that under the culture condition of $20 \%$ of $\mathrm{O}_{2}$ level, the frequency of blastocyst formation and the total cell count were enhanced, and the formation of comet tail (DNA fragmentation) was significantly reduced following supplementation with $100 \mu \mathrm{M}$ of vitamin E [144]. Another similar study was also conducted in sheep with the aim of determining the effects of $\alpha$-TOC supplementation of the oocyte maturation media and embryo culture media on the yield of the embryos. Findings from the study showed that supplementation with $200 \mu \mathrm{M}$ of $\alpha$-TOC in the embryo culture medium at $20 \%$ of $\mathrm{O}_{2}$ level significantly increased the rates of cleavage, formation of morula and blastocysts, and the total cell number of blastocysts, as compared to the control groups [145].

\section{Conclusions}

Vitamin $E$ has received much attention in recent years due to its ability to improve reproductive health. As discussed in the present paper, vitamin E has been reported to exert beneficial effects as an antioxidant against the reproductive disorders. Hence, it is highly recommended for women to consume vitamin E regularly, especially those who are in their reproductive age. However, available study reports on the effects of vitamin E on reproduction, pregnancy, and preimplantation embryonic development are still lacking. Many future studies are necessary in order to gain a greater understanding of the antioxidative role of vitamin E, especially with respect to female reproductive health.

Acknowledgments: We are deeply grateful to the Ministry of Higher Education (MOHE) Malaysia for providing the financial support through the Fundamental Research Grant Scheme (FRGS) (600-IRMI/FRGS 5/3 (037/2017). Thanks are given to all staff and members of the Faculty of Pharmacy, UiTM Selangor, Puncak Alam Campus, and the Faculty of Medicine, UiTM Selangor, Sg. Buloh Campus, Malaysia for all the assistance and support given in the completion of this paper.

Author Contributions: All authors contributed equally to the completion of this paper. Siti Syairah Mohd Mutalip conceived the idea, collected sources of information, and initiated and contributed to manuscript writing. Mohd Hamim Rajikin and Sharaniza Ab-Rahim contributed to manuscript analysis and review; as well as contributed to the manuscript writing.

Conflicts of Interest: The authors declare no conflict of interest.

\section{References}

1. Evans, H.M.; Bishop, K.S. On the existence of a hitherto unrecognized dietary factor essential for reproduction. Science 1922, 56, 650-651. [CrossRef] [PubMed]

2. Tappel, A.L. Vitamin E as the biological lipid antioxidant. Vitam. Horm. 1962, 20, 493-510.

3. Burton, G.W.; Ingold, K.U. Vitamin E application of the principles of physical organic chemistry to the exploration of its structure and function. Acc. Chem. Res. 1986, 19, 194-201. [CrossRef]

4. Esterbauer, H.; Dieber-Rotheneder, M.; Striegl, G.; Waeg, G. Role of vitamin E in preventing the oxidation of low density lipoprotein. Am. J. Clin. Nutr. 1991, 53, 314S-321S. [CrossRef] [PubMed]

5. Sheppard, A.J.; Pennington, J.A.T.; Weihrauch, J.L. Analysis and distribution of vitamin E in vegetable oils and foods. In Vitamin E in Health and Disease; Packer, L., Fuchs, J., Eds.; Marcel Dekker: New York, NY, USA, 1993; pp. 9-31, ISBN 0-8247-8692-0.

6. Ramaswamy, K.; Subash, C.G.; Ji, H.K.; Bharat, B.A. Tocotrienols fight cancer by targeting multiple cell signaling pathways. Genes Nutr. 2012, 7, 43-52. [CrossRef] 
7. Kobayashi, H.; Kanno, C.; Yamauchi, K.; Tsugo, T. Identification of alpha-, beta-, gamma-, and delta-tocopherols and their contents in human milk. Biochim. Biophys. Acta 1975, 380, 282-290. [PubMed]

8. Nehdi, I.; Omri, S.; Khalil, M.I.; Al-Resayes, S.I. Characteristics and chemical composition of date palm (Phoenix canariensis) seeds and seed oil. Ind. Crops Prod. 2010, 32, 360-365. [CrossRef]

9. Tan, B. Vitamin E: Tocotrienols—The Science behind Tocotrienols. Available online: https://assets.kyani. net/documents/us/Tocotrienols_Science_White_Paper-1.12-EN-ALL.pdf (accessed on 14 August 2017).

10. Rimbach, G.; Jennifer, M.; Patricia, H.; John, K.L. Gene-Regulatory Activity of $\alpha$-Tocopherol. Molecules 2010, 15, 1746-1761. [CrossRef] [PubMed]

11. IUPAC-IUB Joint Commission on Biochemical Nomenclature. Nomenclature of tocopherols and related compounds. (Recommendations 1981). Eur. J. Biochem. 1982, 123, 473-475.

12. Rimbach, G.; Minihane, A.M.; Majewicz, J.; Fischer, A.; Pallauf, J.; Virgli, F.; Weinberg, P.D. Regulation of cell signalling by vitamin E. Proc. Nutr. Soc. 2002, 61, 415-425. [CrossRef] [PubMed]

13. Pignitter, M.; Stolze, K.; Gartner, S.; Dumhart, B.; Stoll, C.; Steiger, G.; Kraemer, K.; Somoza, V. Cold fluorescent light as major inducer of lipid oxidation in soybean oil stored at household conditions for eight weeks. J. Agric. Food Chem. 2014, 62, 2297-2305. [CrossRef] [PubMed]

14. The Structure of Vitamin, E. Available online: https://www.omicsonline.org/articles-images/2155-9899-4137-g001.html (accessed on 23 January 2018).

15. Wigle, D.T.; Arbuckle, T.E.; Turner, M.C.; Bérubé, A.; Yang, Q.; Liu, S.; Krewski, D. Epidemiologic evidence of relationships between reproductive and child health outcomes and environmental chemical contaminants. J. Toxicol. Environ. Health B Crit. Rev. 2008, 11, 373-517. [CrossRef] [PubMed]

16. Rider, C.V.; Furr, J.R.; Wilson, V.S.; Gray, L.E., Jr. Cumulative effects of in utero administration of mixtures of reproductive toxicants that disrupt common target tissues via diverse mechanisms of toxicity. J. Androl. 2010, 33, 443-462. [CrossRef] [PubMed]

17. Al-Gubory, K.H. Environmental pollutants and lifestyle factors induce oxidative stress and poor prenatal development. Reprod. Biomed. Online 2014, 29, 17-31. [CrossRef] [PubMed]

18. Kortenkamp, A. Ten years of mixing cocktails: A review of combination effects of endocrine-disrupting chemicals. Environ. Health Perspect. 2007, 115 (Suppl. 1), 98-105. [CrossRef] [PubMed]

19. Luo, Z.C.; Liu, J.M.; Fraser, W.D. Large prospective birth cohort studies on environmental contaminants and child health-Goals, challenges, limitations and needs. Med. Hypotheses 2010, 74, 318-324. [CrossRef] [PubMed]

20. Ruder, E.H.; Hartman, T.J.; Blumberg, J.; Goldman, M.B. Oxidative stress and antioxidants: Exposure and impact on female fertility. Hum. Reprod. Update 2008, 14, 345-357. [CrossRef] [PubMed]

21. Wells, P.G.; McCallum, G.P.; Chen, C.S.; Henderson, J.T.; Lee, C.J.; Perstin, J.; Preston, T.J.; Wiley, M.J.; Wong, A.W. Oxidative stress in developmental origins of disease: Teratogenesis, neurodevelopmental deficits, and cancer. Toxicol. Sci. 2009, 108, 4-18. [CrossRef] [PubMed]

22. Al-Gubory, K.H.; Fowler, P.A.; Garrel, C. The roles of cellular reactive oxygen species, oxidative stress and antioxidants in pregnancy outcomes. Int. J. Biochem. Cell Biol. 2010, 42, 1634-1650. [CrossRef] [PubMed]

23. Agarwal, A.; Aponte-Mellado, A.; Premkumar, B.J.; Shaman, A.; Gupta, S. The effects of oxidative stress on female reproduction: A review. Reprod. Biol. Endocrinol. 2012, 10, 49. [CrossRef] [PubMed]

24. Anderson, K.; Nisenblat, V.; Norman, R. Lifestyle factors in people seeking infertility treatment-A review. Aust. N. Z. J. Obstet. Gynaecol. 2010, 50, 8-20. [CrossRef] [PubMed]

25. Sharma, R.; Biedenharn, K.R.; Fedor, J.M.; Agarwal, A. Lifestyle factors and reproductive health: Taking control of your fertility. Reprod. Biol. Endocrinol. 2013, 11, 66. [CrossRef] [PubMed]

26. Kovacic, P.; Somanathan, R. Mechanism of teratogenesis: Electron transfer, reactive oxygen species, and antioxidants. Birth Defects Res. C Embryo Today 2006, 78, 308-325. [CrossRef] [PubMed]

27. Rasch, V. Cigarette, alcohol, and caffeine consumption: Risk factors for spontaneous abortion. Acta Obstet. Gynecol. Scand. 2003, 82, 182-188. [CrossRef] [PubMed]

28. Weng, X.; Odouli, R.; Li, D.K. Maternal caffeine consumption during pregnancy and the risk of miscarriage: A prospective cohort study. Am. J. Obstet. Gynecol. 2008, 198, 279.e1-279.e8. [CrossRef] [PubMed]

29. Barua, S.; Junaid, M.A. Lifestyle, pregnancy and epigenetic effects. Epigenomics 2015, 7, 85-102. [CrossRef] [PubMed] 
30. Dechanet, C.; Anahory, T.; Mathieu Daude, J.C.; Quantin, X.; Reyftmann, L.; Hamamah, S.; Hedon, B.; Dechaud, H. Effects of cigarette smoking on reproduction. Hum. Reprod. Update 2011, 17, 76-95. [CrossRef] [PubMed]

31. Dembele, K.; Yao, X.H.; Chen, L.; Nyomba, B.L. Intrauterine ethanol exposure results in hypothalamic oxidative stress and neuroendocrine alterations in adult rat offspring. Am. J. Physiol. Regul. Integr. Comp. Physiol. 2006, 291, R796-R802. [CrossRef] [PubMed]

32. Wentzel, P.; Eriksson, U.J. Ethanol-induced fetal dysmorphogenesis in the mouse is diminished by high antioxidative capacity of the mother. Toxicol. Sci. 2006, 92, 416-422. [CrossRef] [PubMed]

33. Wentzel, P.; Rydberg, U.; Eriksson, U.J. Antioxidative treatment diminishes ethanol-induced congenital malformations in the rat. Alcohol. Clin. Exp. Res. 2006, 30, 1752-1760. [CrossRef] [PubMed]

34. Van Gelder, M.M.; van Rooij, I.A.; Miller, R.K.; Zielhuis, G.A.; de Jong-van den Berg, L.T.; Roeleveld, N. Teratogenic mechanisms of medical drugs. Hum. Reprod. Update 2010, 16, 378-394. [CrossRef] [PubMed]

35. Deavall, D.G.; Martin, E.A.; Horner, J.M.; Roberts, R. Drug-induced oxidative stress and toxicity. J. Toxicol. 2012. [CrossRef] [PubMed]

36. Liu, L.; Wells, P.G. In vivo phenytoin-initiated oxidative damage to proteins and lipids in murine maternal hepatic and embryonic tissue organelles: Potential molecular targets of chemical teratogenesis. Toxicol. Appl. Pharmacol. 1994, 125, 247-255. [CrossRef] [PubMed]

37. Hansen, J.M.; Harris, C. A novel hypothesis for thalidomide-induced limb teratogenesis: Redox misregulation of the NF-kappaB pathway. Antioxid. Redox Signal. 2004, 6, 1-14. [CrossRef] [PubMed]

38. Defoort, E.N.; Kim, P.M.; Winn, L.M. Valproic acid increases conservative homologous recombination frequency and reactive oxygen species formation: A potential mechanism for valproic acid-induced neural tube defects. Mol. Pharmacol. 2006, 69, 1304-1310. [CrossRef] [PubMed]

39. Danielsson, B.R.; Danielsson, C.; Nilsson, M.F. Embryonic cardiac arrhythmia and generation of reactive oxygen species: Common teratogenic mechanism for IKr blocking drugs. Reprod. Toxicol. 2007, 24, 42-56. [CrossRef] [PubMed]

40. Borgerding, M.; Klus, H. Analysis of complex mixtures-Cigarette smoke. Exp. Toxicol. Pathol. 2005, 57, 43-73. [CrossRef] [PubMed]

41. Feltes, B.C.; de Faria Poloni, J.; Notari, D.L.; Bonatto, D. Toxicological effects of the different substances in tobacco smoke on human embryonic development by a systems chemo-biology approach. PLoS ONE 2013, 8, e61743. [CrossRef] [PubMed]

42. George, L.; Granath, F.; Johansson, A.L.; Anneren, G.; Cnattingius, S. Environmental tobacco smoke and risk of spontaneous abortion. Epidemiology 2006, 17, 500-505. [CrossRef] [PubMed]

43. Ananth, C.V.; Smulian, J.C.; Vintzileos, A.M. Incidence of placental abruption in relation to cigarette smoking and hypertensive disorders during pregnancy: A meta-analysis of observational studies. Obstet. Gynecol. 1999, 93, 622-628. [CrossRef] [PubMed]

44. Faiz, A.S.; Ananth, C.V. Etiology and risk factors for placenta previa: An overview and meta-analysis of observational studies. J. Matern. Fetal Neonatal Med. 2003, 13, 175-190. [CrossRef] [PubMed]

45. Hung, T.H.; Hsieh, C.C.; Hsu, J.J.; Chiu, T.H.; Lo, L.M.; Hsieh, T.T. Risk factors for placenta previa in an Asian population. Int. J. Gynaecol. Obstet. 2007, 97, 26-30. [CrossRef] [PubMed]

46. Kolas, T.; Nakling, J.; Salvesen, K.A. Smoking during pregnancy increases the risk of preterm births among parous women. Acta Obstet. Gynecol. Scand. 2000, 79, 644-648. [PubMed]

47. Fantuzzi, G.; Aggazzotti, G.; Righi, E.; Facchinetti, F.; Bertucci, E.; Kanitz, S.; Barbone, F.; Sansebastiano, G.; Battaglia, M.A.; Leoni, V.; et al. Preterm delivery and exposure to active and passive smoking during pregnancy: A case-control study from Italy. Paediatr. Perinat. Epidemiol. 2007, 21, 194-200. [CrossRef] [PubMed]

48. Jaddoe, V.W.; Troe, E.J.; Hofman, A.; Mackenbach, J.P.; Moll, H.A.; Steegers, E.A.; Witteman, J.C. Active and passive maternal smoking during pregnancy and the risks of low birthweight and preterm birth: The Generation R Study. Paediatr. Perinat. Epidemiol. 2008, 22, 162-171. [CrossRef] [PubMed]

49. Wisborg, K.; Kesmodel, U.; Henriksen, T.B.; Olsen, S.F.; Secher, N.J. Exposure to tobacco smoke in utero and the risk of stillbirth and death in the first year of life. Am. J. Epidemiol. 2001, 154, 322-327. [CrossRef] [PubMed]

50. Hogberg, L.; Cnattingius, S. The influence of maternal smoking habits on the risk of subsequent stillbirth: Is there a causal relation? BJOG 2007, 114, 699-704. [CrossRef] [PubMed] 
51. Mitchell, E.A.; Milerad, J. Smoking and the sudden infant death syndrome. Rev. Environ. Health 2006, 21, 81-103. [CrossRef] [PubMed]

52. Sharpe, R.M.; Franks, S. Environment, lifestyle and infertility-An inter-generational issue. Nat. Cell Biol. 2002, 4, s33-s40. [CrossRef] [PubMed]

53. Zenzes, M.T.; Krishnan, S.; Krishnan, B.; Zhang, H.; Casper, R.F. Cadmium accumulation in follicular fluid of women in in vitro fertilization-embryo transfer is higher in smokers. Fertil. Steril. 1995, 64, 599-603. [CrossRef]

54. Younglai, E.V.; Foster, W.G.; Hughes, E.G.; Trim, K.; Jarrell, J.F. Levels of environmental contaminants in human follicular fluid, serum, and seminal plasma of couples undergoing in vitro fertilization. Arch. Environ. Contam. Toxicol. 2002, 43, 121-126. [CrossRef] [PubMed]

55. Neal, M.S.; Zhu, J.; Foster, W.G. Quantification of benzo[a]pyrene and other PAHs in the serum and follicular fluid of smokers versus non-smokers. Reprod. Toxicol. 2008, 25, 100-106. [CrossRef] [PubMed]

56. Van Voorhis, B.J.; Dawson, J.D.; Stovall, D.W.; Sparks, A.E.; Syrop, C.H. The effects of smoking on ovarian function and fertility during assisted reproduction cycles. Obstet. Gynecol. 1996, 88, 785-791. [CrossRef]

57. Ness, R.B.; Grisso, J.A.; Hirschinger, N.; Markovic, N.; Shaw, L.M.; Day, N.L.; Kline, J. Cocaine and tobacco use and the risk of spontaneous abortion. N. Engl. J. Med. 1999, 340, 333-339. [CrossRef] [PubMed]

58. Huang, J.; Okuka, M.; McLean, M.; Keefe, D.L.; Liu, L. Effects of cigarette smoke on fertilization and embryo development in vivo. Fertil. Steril. 2009, 92, 1456-1465. [CrossRef] [PubMed]

59. Zhao, Z.; Reece, E.A. Nicotine-induced embryonic malformations mediated by apoptosis from increasing intracellular calcium and oxidative stress. Birth Defects Res. B Dev. Reprod. Toxicol. 2005, 74, 383-391. [CrossRef] [PubMed]

60. Holloway, A.C.; Kellenberger, L.D.; Petrik, J.J. Fetal and neonatal exposure to nicotine disrupts ovarian function and fertility in adult female rats. Endocrine 2006, 30, 213-216. [CrossRef]

61. Mokhtar, N.; Rajikin, M.H.; Zakaria, Z. Role of tocotrienol-rich palm vitamin E on pregnancy and preimplantation embryos in nicotine treated rats. Biomed. Res. 2008, 19, 181-184.

62. Rajikin, M.H.; Latif, E.S.; Mar, M.R.; Mat Top, A.G.; Mokhtar, N.M. Deleterious effects of nicotine on the ultrastructure of oocytes: Role of gamma-tocotrienol. Med. Sci. Monit. 2009, 15, BR378-BR383. [PubMed]

63. Asadi, E.; Mehrdad, J.; Mohammad, J.G. Effect of vitamin E on oocytes apoptosis in nicotine-treated mice. Iran. J. Basic Med. Sci. 2012, 15, 880-884. [PubMed]

64. Kamsani, Y.S.; Rajikin, M.H.; Nor-Ashikin, M.N.K.; Nuraliza, A.S.; Chatterjee, A. Nicotine-induced cessation of embryonic development is reversed by $\gamma$-tocotrienol in mice. Med. Sci. Monit. Basic Res. 2013, 19, 87-92. [CrossRef] [PubMed]

65. Phoebe, C.J.; Julie, A.M.; Emma, L.B.; Philip, M.H.; Keith, T.J. Increased zona pellucida thickness and meiotic spindle disruption in oocytes from cigarette smoking mice. Hum. Reprod. 2011, 26, 878-884. [CrossRef]

66. Agarwal, A.; Gupta, S.; Sekhon, L.; Shah, R. Redox considerations in female reproductive function and assisted reproduction: From molecular mechanisms to health implications. Antioxid. Redox Signal. 2008, 10, 1375-1403. [CrossRef] [PubMed]

67. Ames, B.N.; Shigenaga, M.K.; Hagen, T.M. Oxidants, antioxidants, and the degenerative diseases of aging. Proc. Natl. Acad. Sci. USA 1993, 90, 7915-7922. [CrossRef] [PubMed]

68. Puglia, C.D.; Powell, S.R. Inhibition of cellular antioxidants: A possible mechanism of toxic cell injury. Environ. Health Perspect. 1984, 57, 307-311. [CrossRef] [PubMed]

69. Evans, M.D.; Dizdaroglu, M.; Cooke, M.S. Oxidative DNA damage and disease: Induction, repair and significance. Mutat. Res. 2004, 567, 1-61. [CrossRef] [PubMed]

70. Dennery, P.A. Role of redox in fetal development and neonatal diseases. Antioxid. Redox Signal. 2004, 6, 147-153. [CrossRef] [PubMed]

71. Lee, T.H.; Wu, M.Y.; Chen, M.J.; Chao, K.H.; Ho, H.N.; Yang, Y.S. Nitric oxide is associated with poor embryo quality and pregnancy outcome in in vitro fertilization cycles. Fertil. Steril. 2004, 82, 126-131. [CrossRef] [PubMed]

72. Sharma, R.K.; Agarwal, A. Role of reactive oxygen species in gynecologic diseases. Reprod. Med. Biol. 2004, 3, 177-199. [CrossRef]

73. Guerin, P.; El Mouatassim, S.; Menezo, Y. Oxidative stress and protection against reactive oxygen species in the pre-implantation embryo and its surroundings. Hum. Reprod. Update 2001, 7, 175-189. [CrossRef] [PubMed] 
74. Agarwal, A.; Saleh, R.A.; Bedaiwy, M.A. Role of reactive oxygen species in the pathophysiology of human reproduction. Fertil. Steril. 2003, 79, 829-843. [CrossRef]

75. Jurisicova, A.; Varmuza, S.; Casper, R.F. Programmed cell death and human embryo fragmentation. Mol. Hum. Reprod. 1996, 2, 93-98. [CrossRef] [PubMed]

76. Walsh, S.W.; Wang, Y. Secretion of lipid peroxides by the human placenta. Am. J. Obstet. Gynecol. 1993, 169, 1462-1466. [CrossRef]

77. Myatt, L.; Cui, X. Oxidative stress in the placenta. Histochem. Cell Biol. 2004, 122, 369-382. [CrossRef] [PubMed]

78. Poston, L.; Raijmakers, M.T. Trophoblast oxidative stress, antioxidants and pregnancy outcome-A review. Placenta 2004, 25 (Suppl. A), S72-S78. [CrossRef] [PubMed]

79. Wang, Y.; Walsh, S.W. Placental mitochondria as a source of oxidative stress in pre-eclampsia. Placenta 1998, 19, 581-586. [CrossRef]

80. Jauniaux, E.; Watson, A.L.; Hempstock, J.; Bao, Y.; Skepper, J.N.; Burton, G.J. Onset of maternal arterial blood flow and placental oxidative stress: A possible factor in human early pregnancy failure. Am. J. Pathol. 2000, 157, 2111-2122. [CrossRef]

81. Parman, T.; Wiley, M.J.; Wells, P.G. Free radical-mediated oxidative DNA damage in the mechanism of thalidomide teratogenicity. Nat. Med. 1999, 5, 582-585. [PubMed]

82. Burton, G.J.; Hempstock, J.; Jauniaux, E. Oxygen, early embryonic metabolism and free radical-mediated embryopathies. Reprod. Biomed. Online 2003, 6, 84-96. [CrossRef]

83. Nicol, C.J.; Zielenski, J.; Tsui, L.C.; Wells, P.G. An embryoprotective role for glucose-6-phosphate dehydrogenase in developmental oxidative stress and chemical teratogenesis. FASEB J. 2000, 14, 111-127. [CrossRef] [PubMed]

84. Murphy, A.A.; Santanam, N.; Parthasarathy, S. Endometriosis: A disease of oxidative stress? Semin. Reprod. Endocrinol. 1998, 16, 263-273. [CrossRef] [PubMed]

85. Rong, R.; Ramachandran, S.; Santanam, N.; Murphy, A.A.; Parthasarathy, S. Induction of monocyte chemotactic protein-1 in peritoneal mesothelial and endometrial cells by oxidized low-density lipoprotein and peritoneal fluid from women with endometriosis. Fertil. Steril. 2002, 78, 843-848. [CrossRef]

86. Szczepanska, M.; Kozlik, J.; Skrzypczak, J.; Mikolajczyk, M. Oxidative stress may be a piece in the endometriosis puzzle. Fertil. Steril. 2003, 79, 1288-1293. [CrossRef]

87. Bedaiwy, M.A.; Falcone, T. Peritoneal fluid environment in endometriosis. Clinicopathological implications. Minerva Ginecol. 2003, 55, 333-345. [PubMed]

88. Jackson, L.W.; Schisterman, E.F.; Dey-Rao, R.; Browne, R.; Armstrong, D. Oxidative stress and endometriosis. Hum. Reprod. 2005, 20, 2014-2020. [CrossRef] [PubMed]

89. Mier-Cabrera, M.; Jimenez-Zamudio, L.; Garcia-Latorre, E.; Cruz-Orozco, O.; Hernandez-Guerrero, C. Quantitative and qualitative peritoneal immune profiles, T-cell apoptosis and oxidative stress-associated characteristics in women with minimal and mild endometriosis. BJOG 2011, 118, 6-16. [CrossRef] [PubMed]

90. Sharma, I.; Dhaliwal, L.K.; Saha, S.C.; Sangwan, S.; Dhawan, V. Role of 8-iso-prostaglandin F 2alpha and 25-hydroxycholesterol in the pathophysiology of endometriosis. Fertil. Steril. 2010, 94, 63-70. [CrossRef] [PubMed]

91. Gupta, S.; Agarwal, A.; Banerjee, J.; Alvarez, J.G. The role of oxidative stress in spontaneous abortion and recurrent pregnancy loss: A systematic review. Obstet. Gynecol. Surv. 2007, 62, 335-347. [CrossRef] [PubMed]

92. Polak, G.; Rola, R.; Gogacz, M.; Koziol-Montewka, M.; Kotarski, J. Malonyldialdehyde and total antioxidant status in the peritoneal fluid of infertile women. Ginekol. Pol. 1999, 70, 135-140. [PubMed]

93. Polak, G.; Koziol-Montewka, M.; Tarkowski, R.; Kotarski, J. Peritoneal fluid and plasma 4-hydroxynonenal and malonyldialdehyde concentrations in infertile women. Ginekol. Pol. 2011, 72, 1316-1320.

94. Agarwal, A.; Gupta, S.; Sikka, S. The role of free radicals and antioxidants in reproduction. Curr. Opin. Obstet. Gynecol. 2006, 18, 325-332. [CrossRef] [PubMed]

95. Burton, G.J.; Jauniaux, E. Placental oxidative stress: From miscarriage to preeclampsia. J. Soc. Gynecol. Investig. 2004, 11, 342-352. [CrossRef] [PubMed]

96. Redman, C.W.; Sargent, I.L. Placental stress and pre-eclampsia: A revised view. Placenta 2009, 30 (Suppl. A), S38-S42. [CrossRef] [PubMed]

97. Burton, G.J.; Yung, H.W.; Cindrova-Davies, T.; Charnock-Jones, D.S. Placental endoplasmic reticulum stress and oxidative stress in the pathophysiology of unexplained intrauterine growth restriction and early onset preeclampsia. Placenta 2009, 30 (Suppl. A), S43-S48. [CrossRef] [PubMed] 
98. Karowicz-Bilinska, A. Lipid peroxides concentration in women with intrauterine growth restriction. Ginekol. Pol. 2004, 75, 6-9. [PubMed]

99. Biri, A.; Bozkurt, N.; Turp, A.; Kavutcu, M.; Himmetoglu, O.; Durak, I. Role of oxidative stress in intrauterine growth restriction. Gynecol. Obstet. Investig. 2007, 64, 187-192. [CrossRef] [PubMed]

100. Hong, Y.C.; Lee, K.H.; Yi, C.H.; Ha, E.H.; Christiani, D.C. Genetic susceptibility of term pregnant women to oxidative damage. Toxicol. Lett. 2002, 129, 255-262. [CrossRef]

101. Frosali, S.; DiSimplicio, P.; Perrone, S.; DiGiuseppe, D.; Longini, M.; Tanganelli, D.; Buonocore, G. Glutathione recycling and antioxidant enzyme activities in erythrocytes of term and preterm newborns at birth. Neonatology 2004, 85, 188-194. [CrossRef] [PubMed]

102. Mustafa, M.D.; Pathak, R.; Ahmed, T.; Ahmed, R.S.; Tripathi, A.K.; Guleria, K.; Banerjee, B.D. Association of glutathione S-transferase M1 and T1 gene polymorphisms and oxidative stress markers in preterm labor. Clin. Biochem. 2010, 43, 1124-1128. [CrossRef] [PubMed]

103. Pathak, R.; Suke, S.G.; Ahmed, T.; Ahmed, R.S.; Tripathi, A.K.; Guleria, K.; Sharma, C.S.; Makhijani, S.D.; Banerjee, B.D. Organochlorine pesticide residue levels and oxidative stress in preterm delivery cases. Hum. Exp. Toxicol. 2010, 29, 351-358. [CrossRef] [PubMed]

104. Perkins, A.V. Anti-oxidants in pregnancy Endogenous anti-oxidants in pregnancy and preeclampsia. Aust. N. Z. J. Obstet. Gynaecol. 2006, 46, 77-83. [CrossRef] [PubMed]

105. Mustacich, D.; Powis, G. Thioredoxin reductase. Biochem. J. 2000, 346, 1-8. [CrossRef] [PubMed]

106. Rhee, S.G.; Chae, H.Z.; Kim, K. Peroxiredoxins: A historical overview and speculative preview of novel mechanisms and emerging concepts in cell signaling. Free Radic. Biol. Med. 2005, 38, 1543-1552. [CrossRef] [PubMed]

107. Gasdaska, J.R.; Berggren, M.; Powis, G. Cell growth stimulation by the redox protein thioredoxin occurs by a novel helper mechanism. Cell Growth Differ. 1995, 6, 1643-1650. [PubMed]

108. Saitoh, M.; Nishitoh, H.; Fujii, M.; Takeda, K.; Tobiume, K.; Sawada, Y.; Kawabata, M.; Miyazono, K.; Ichijo, H. Mammalian thioredoxin is a direct inhibitor of apoptosis signal-regulating kinase (ASK) 1. EMBO J. 1998, 17, 2596-2606. [CrossRef] [PubMed]

109. Nordberg, J.; Arner, E.S.J. Reactive oxygen species, antioxidants, and the mammalian thioredoxin system. Free Radic. Biol. Med. 2001, 31, 1287-1312. [CrossRef]

110. Aerts, L.; Van, A.F.A. Taurine and taurine-deficiency in the perinatal period. J. Perinat. Med. 2002, 30, $281-286$. [CrossRef] [PubMed]

111. Uriu-Adams, J.Y.; Keen, C.L. Zinc and reproduction: Effects of zinc deficiency on prenatal and early postnatal development. Birth Defects Res. B. Dev. Reprod. Toxicol. 2010, 89, 313-325. [CrossRef] [PubMed]

112. Silvia, I.A.; Castañón, S.G.; Ruata, M.L.; Aragüés, E.F.; Terraz, P.B.; Irazabal, Y.G.; González, E.G.; Rodríguez, B.G. Updating of normal levels of copper, zinc and selenium in serum of pregnant women. J. Trace Elem. Med. Biol. 2007, 21 (Suppl. 1), 49-52. [CrossRef]

113. Hess, S.Y.; King, J.C. Effects of maternal zinc supplementation on pregnancy and lactation outcomes. Food Nutr. Bull. 2009, 30 (Suppl. 1), S60-S78. [CrossRef] [PubMed]

114. Levine, M.; Katz, A.; Padayatty, S.J.; Vitamin, C. Modern Nutrition in Health and Disease; Shils, M.E., Shike, M., Ross, A.C., Caballero, B., Cousins, R.J., Eds.; Lippincott Williams \& Wilkins: Philadelphia, PA, USA, 2006; pp. 507-524.

115. Zhang, C.; Williams, M.A.; King, I.B.; Dashow, E.E.; Sorensen, T.K.; Frederick, I.O.; Thompson, M.L.; Luthy, D.A. Vitamin C and the risk of preeclampsia—Results from dietary questionnaire and plasma assay. Epidemiology 2002, 13, 409-416. [CrossRef] [PubMed]

116. Henmi, H.; Endo, T.; Kitajima, Y.; Manase, K.; Hata, H.; Kudo, R. Effects of ascorbic acid supplementation on serum progesterone levels in patients with a luteal phase defect. Fertil. Steril. 2003, 80, 459-461. [CrossRef]

117. Westphal, L.M.; Polan, M.L.; Trant, A.S.; Mooney, S.B. A nutritional supplement for improving fertility in women: A pilot study. J. Reprod. Med. 2004, 49, 289-293. [PubMed]

118. Rumiris, D.; Purwosunu, Y.; Wibowo, N.; Farina, A.; Sekizawa, A. Lower rate of preeclampsia after antioxidant supplementation in pregnant women with low antioxidant status. Hypertens. Pregnancy 2006, 25, 241-253. [CrossRef] [PubMed]

119. Traber, M.G.; Jeffrey, A. Vitamin E, antioxidant and nothing more. Free Radic. Biol. Med. 2007, 43, 4-15. [CrossRef] [PubMed] 
120. Fraser, W.D.; Audibert, F.; Bujold, E.; Leduc, L.; Xu, H.; Boulvain, M.; Julien, P. The Vitamin E debate: Implications for ongoing trials of pre-eclampsia prevention. BJOG 2005, 112, 684-688. [CrossRef] [PubMed]

121. Parvin, B.; Kobra, H.; Fatemeh, A.; Nazli, N. Effects of vitamin E supplementation on some pregnancy health indices: A randomized clinical trial. Int. J. Gen. Med. 2011, 4, 461-464. [CrossRef]

122. De Vriese, S.R.; Dhont, M.; Christophe, A.B. Oxidative stability of low density lipoproteins and vitamin $\mathrm{E}$ levels increase in maternal blood during normal pregnancy. Lipids 2001, 36, 361-366. [CrossRef] [PubMed]

123. Chelchowska, M.; Laskowska-Klita, T.; Leibschang, J. The effect of tobacco smoking during pregnancy on concentration of vitamin $\mathrm{E}$ in blood of mothers and their newborns in umbilical cord blood. Ginekol. Pol. 2006, 77, 263-268. [PubMed]

124. Von Mandach, U.; Huch, R.; Huch, A. Maternal and cord serum vitamin E levels in normal and abnormal pregnancy. Int. J. Vitam. Nutr. Res. 1994, 64, 26-32. [PubMed]

125. Tamura, T.; Goldenberg, R.L.; Johnston, K.E.; Cliver, S.P.; Hoffman, H.J. Serum concentrations of zinc, folate, vitamins $\mathrm{A}$ and $\mathrm{E}$, and proteins, and their relationships to pregnancy outcome. Acta Obstet. Gynecol. Scand. Suppl. 1997, 165, 63-70. [PubMed]

126. Cicek, N.; Eryilmaz, O.G.; Sarikaya, E.; Gulerman, C.; Genc, Y. Vitamin E effect on controlled ovarian stimulation of unexplained infertile women. J. Assist. Reprod. Genet. 2012, 29, 325-328. [CrossRef] [PubMed]

127. Traber, G.M. Vitamin E Inadequacy in Humans: Causes and Consequences. Adv. Nutr. 2014, 5, 503-514. [CrossRef] [PubMed]

128. Barrie, M.M. Vitamin E deficiency in rats: Fertility in the female. Biochem. J. 1938, 32, 2134-2137. [CrossRef] [PubMed]

129. Simsek, M.; Naziroglu, M.; Simsek, H.; Cay, M.; Aksakal, M.; Kumru, S. Blood plasma levels of lipoperoxides, glutathione peroxidase, beta carotene, vitamin A and $\mathrm{E}$ in women with habitual abortion. Cell Biochem. Funct. 1998, 16, 227-231. [CrossRef]

130. Ibrahim, S.A.; Abd el-Maksoud, A.; Nassar, M.F. Nutritional stunting in Egypt: Which nutrient is responsible? East. Mediterr. Health J. 2002, 8, 272-280. [PubMed]

131. Fares, S.; Sethom, M.M.; Khouaja-Mokrani, C.; Jabnoun, S.; Feki, M.; Kaabachi, N. Vitamin A, E, and D deficiencies in Tunisian very low birth weight neonates: Prevalence and risk factors. Pediatr. Neonatol. 2014, 55, 196-201. [CrossRef] [PubMed]

132. Saleh, H.; Omar, E.; Froemming, G.; Said, R. Tocotrienol rich fraction supplementation confers protection on the ovary from cyclophasphamide induced apoptosis. Asian Pac. J. Trop. Dis. 2014, 4, 234. [CrossRef]

133. Saleh, H.; Omar, E.; Froemming, G.; Said, R. Tocotrienol preserves ovarian function in cyclophosphamide therapy. Hum. Exp. Toxicol. 2015, 34, 946-952. [CrossRef] [PubMed]

134. Nasibah, A.; Rajikin, M.H.; Nor-Ashikin, M.N.K.; Nuraliza, A.S. Tocotrienol improves the quality of impaired mouse embryos induced by corticosterone. In Proceedings of the Symposium on Humanities, Science and Engineering Research (SHUSER2012), Kuala Lumpur, Malaysia, 24-27 June 2012; pp. 135-138.

135. Lee, E.; Min, S.-H.; Song, B.-S.; Yeon, J.-Y.; Kim, J.-W.; Bae, J.-H.; Park, S.-Y.; Lee, Y.-H.; Kim, S.-U.; Lee, D.-S.; et al. Exogenous $\gamma$-tocotrienol promotes preimplantation development and improves the quality of porcine embryos. Reprod. Fertil. Dev. 2014. [CrossRef] [PubMed]

136. Paumgartten, F.J.R.; De-Carvalho, R.R.; Araujo, I.B.; Pinto, F.M.; Borges, O.O.; Souza, C.A.M.; Kuriyama, S.M. Evaluation of the developmental toxicity of annatto in the rat. Food Chem. Toxicol. 2002, 40, 1595-1601. [CrossRef]

137. Syairah, S.M.M.; Rajikin, M.H.; Sharaniza, A.-R.; Nor-Ashikin, M.N.K.; Anne, T.; Barrie, T. Annatto (Bixa orellana) derived $\delta$-tocotrienol supplementation suppresses PIK3CA oncogene expression in 2- and 4-cell embryos of nicotine-induced mice. Anticancer Res. 2014, 34, 6064.

138. Syairah, S.M.M.; Rajikin, M.H.; Sharaniza, A.-R. Supplementation of annatto (Bixa orellana)-derived $\delta$-tocotrienol produced high number of morula through increased expression of 3-phosphoinositide dependent protein kinase-1 (PDK1) in mice. Int. J. Biol. Biomol. Agric. Food Biotechnol. Eng. 2015, 9, 741-745.

139. Syairah, S.M.M.; Rajikin, M.H.; Sharaniza, A.R.; Nor-Ashikin, N.K.; Kamsani, Y.S. Chromosomal status in murine preimplantation 2-cell embryos following annatto (Bixa orellana)-derived pure delta-tocotrienol supplementation in normal and nicotine-treated mice. WASJ 2016, 34, 1855-1859. [CrossRef]

140. Syairah, S.M.M.; Rajikin, M.H.; Sharaniza, A.R.; Nor-Ashikin, M.N.K. Annatto (Bixa orellana) $\delta$-TCT supplementation protected against embryonic DNA damages through alterations in PI3K/Akt-Cyclin D1 pathway. Int. J. Vitam. Nutr. Res. 2017, accepted. 
141. Sugahara, R.; Sato, A.; Uchida, A.; Shiozawa, S.; Sato, C.; Virgona, N.; Yano, T. Annatto tocotrienol induces a cytotoxic effect on human prostate cancer PC3 cells via the simultaneous inhibition of Src and Stat3. J. Nutr. Sci. Vitaminol. 2015, 61, 497-501. [CrossRef] [PubMed]

142. Olson, S.E.; Seidel, G.E., Jr. Culture of in vitro-produced bovine embryos with vitamin E improves development in vitro and after transfer to recipients. Biol. Reprod. 2000, 62, 248-252. [CrossRef] [PubMed]

143. Kitagawa, Y.; Suzuki, K.; Yoneda, A.; Watanabe, T. Effects of oxygen concentration and antioxidants on the in vitro developmental ability, production of reactive oxygen species (ROS), and DNA fragmentation in porcine embryos. Theriogenology 2004, 62, 1186-1197. [CrossRef] [PubMed]

144. Thiyagarajan, B.; Valivittan, K. Ameliorating effect of vitamin E on in vitro development of preimplantation buffalo embryos. J. Assist. Reprod. Genet. 2009, 26, 217-225. [CrossRef] [PubMed]

145. Natarajan, R.; Shankar, M.B.; Munuswamy, D. Effect of $\alpha$-tocopherol supplementation on in vitro maturation of sheep oocytes and in vitro development of preimplantation sheep embryos to the blastocyst stage. J. Assist. Reprod. Genet. 2010, 27, 483-490. [CrossRef] [PubMed]

(C) 2018 by the authors. Licensee MDPI, Basel, Switzerland. This article is an open access article distributed under the terms and conditions of the Creative Commons Attribution (CC BY) license (http://creativecommons.org/licenses/by/4.0/). 